\title{
THE EFFECT OF SERVICE FAILURE, RECOVERY EFFORTS, \& REGRET ON SWITCHING INTENTION TO AXA MANDIRI LIFE ASSURANCE CUSTOMERS IN SURABAYA
}

\author{
MESSY SALAKAY, ANTONIUS JAN WELLYANTONY
}

Department of Management, Universities Katolik Widya Mandala Surabaya, Indonesia

\begin{abstract}
This study aims to analyze the effect of service failure and recovery efforts on switching intention mediated by regret on AXA Mandiri life insurance customers in Surabaya. The sampling technique used is non-probability with purposive sampling. The sample currently used is 150 respondents. The requirements of the respondents in this study are at least 18 years old, domiciled in Surabaya, are customers of AXA Mandiri insurance, and have experienced service failure. The data analysis technique used is SEM with the LISREL program.
\end{abstract}

The results of this study indicate that service failure has a positive and significant effect on regret, but has a negative and insignificant effect on switching intention. Recovery efforts have a negative and insignificant effect on regret and negative and insignificant effect on switching intention. Service failure has a positive and significant effect on switching intention through regret, while recovery efforts has a negative and insignificant effect on switching intention through regret and positive and significant effect on switching intention.

Suggestions from researchers for AXA Mandiri Surabaya insurance is that companies need to develop strategies to prevent service failures and apply appropriate and effective recovery efforts so that they can reduce regrets that result in switching intention.

Keywords: Service Failure, Recovery Efforts, Regret, Switching Intention.

\subsection{INTRODUCTION}

There are several types of insurance in Indonesia, one of which is life insurance. Life insurance is a company that provides services for consumers in risk management that provides payments to policyholders in the event of death or survival, or other payments to policyholders who are entitled at a certain time with the amount stipulated in the agreement (Otoritas Jasa Keuangan, 2017).

PT AXA Mandiri Financial Services (AXA Mandiri) is a joint life insurance company between PT Bank Mandiri (Persero) Tbk and National Mutual International Pty. Limited (AXA). This AXA Mandiri company has been present in Indonesia for more than 15 years to empower Indonesian consumers to have a better quality of life. In Indonesia itself, AXA Mandiri already has a fairly strong and well-known position. This can also be seen from the achievements, where AXA Mandiri took third place in a survey conducted by Top Brand in 2015 for the life insurance category. Although PT AXA Mandiri is in the third position with a fairly strong market, PT AXA Mandiri often gets complaints from its customers. This of course causes a sense of regret (regret) and disappointment for customers or consumers with the services of insurance PT. AXA Mandiri, how can a big brand that has been operating for more than 15 years do something like this. Regret arises from comparing the results obtained with better results that might occur if there were other options (Bui, Krishen and Bates, 2011). 
Regret was identified as the main negative emotion usually associated with self-blame (Bonifield and Cole, 2007). Customers who experience regret tend to take certain actions, such as venting it to third parties, or even switching (Switching Intention) to other products. Someone who experiences regret tends to avoid experiencing the same incident as the previous experience (Huang and Zeelenberg, 2012). Evidently due to the emergence of regrets, the AXA Mandiri insurance index dropped to fourth in 2018.

\section{Tabel 1.1}

Top Brand Index Fase 12018

\begin{tabular}{|c|c|c|}
\hline \multicolumn{3}{|c|}{ ASURANSI JIWA } \\
\hline BRAND & TBI 2018 & \\
\hline Prudential Life Assurance & $29,8 \%$ & TOP \\
\hline Jiwasraya & $9,0 \%$ & \\
\hline AJB Bumiputera 1912 & $9,0 \%$ & \\
\hline AXA Mandiri & $8,8 \%$ & \\
\hline Allianz Life Indonesia & $6,7 \%$ & \\
\hline
\end{tabular}

Sumber: Top Brand Award (2018)

According to Le and Ho (2019), the severity of service failure has the strongest effect on frustration, followed by regret and anger. When a service failure occurs, the service provider, namely the insurance company AXA Mandiri, should have made recovery efforts to fix the problem by apologizing, compensating for losses to consumers, and intervening or intervening to prevent negative emotions from occurring. consumers who may influence consumer decisions in the future (Liat, Mansori, Chuan, and Imrie, 2017).

The business transformation carried out by AXA Mandiri in preventing Regret by carrying out recovery efforts, made PT AXA Mandiri occupy the second position in the 2019 TOP Brand survey while increasing AXA Mandiri's net profit to Rp 1 trillion, an increase of 6\% compared to 2018 which amounted to Rp 946. .6 billion (Liputan6.com, 2020).

Based on this phenomenon, this research will examine the effect of service failure and recovery efforts on switching intention mediated by regret to PT AXA Mandiri's life insurance customers in Surabaya.

\subsection{LITERATURE REVIEW}

\subsection{Service Failure}

According to Hoffman, et al. (2016), in Le and Ho, 2019) service failure is defined as the inability of service providers to meet customer expectations. Meanwhile, according to Gelbrich (2010, in Le and Ho, 2019) service failure refers to costs or losses that must be borne by consumers in terms of money, time, and inconvenience.

Service failure is when the service provided is not in accordance with consumer expectations (Chou, et al., 2009; in Pujiah and Fatmawati, 2018).

\subsection{Recovery Efforts}

According to Liat, et al. (2017, in Le and Ho, 2019) recovery efforts are usually evaluated in terms of fairness which consists of distributive, interactional and procedural justice. According to $\mathrm{Xu}$, Liu, and Gursoy (2018), positive attitudes and behaviors of employees and the accuracy of service recovery have a greater influence in generating positive emotions and reducing negative emotions.

\subsection{Regret}


Regret is identified as the main negative emotion that is usually associated with self-blame when realizing or imagining that the current situation would be better if they chose a different course of action (Bonfield and Cole, 2007; in Le and Ho, 2019). According to Le and Ho (2019), regret can be a negative emotion when looking to the past. Consumers who experience regret have a sense of self-blame and want to improve the current situation, imagining that they can make better choices. Buchanan, Lehman, and Reb (2016) argue that regret permeates people's lives. When making decisions, consumers anticipate regret and try to avoid it, and when receiving negative results consumers often experience regret. According to Pujiah and Fatmawati (2018), the experience of regret shows that there are actually other better alternatives.

\subsection{Switching Intention}

According to Chuang and Tai (2016), switching intention is the tendency of customers to switch to other companies. According to Hui, et al. (2011, in Le and Ho, 2019) the increasing number of service providers in a rapidly growing economy allows switching intentions to other brands to be easy when consumers regret not choosing another option.

Jabeen, Hamid, and Rehman (2015) say that switching intention is one of the signs to terminate the relationship with the current service provider, either partially or completely.

\subsection{Previous Research}

The first previous research used as a reference in this study was conducted by Le and Ho (2019). The study aimed to investigate the set of behavioral consequences used by customers in overcoming each negative emotion in the context of Vietnamese-Confucian culture. The result of this research is that service failure has the strongest effect on frustration and is followed by regret and anger being the lowest. Customers who experience regret tend to take actions such as venting to a third party or switching to another brand or service.

\subsection{Hypothesis \& Model}

H1: Service failure effect on regret.

H2: Recovery efforts have a negative effect on regret.

H3: Service failure affects switching intention.

H4: Recovery efforts have a negative effect on switching intention.

H5: Service failure affects switching intention through regret.

H6: Recovery efforts have a negative effect on switching intention through regret.

H7: Regret effect on switching intention.

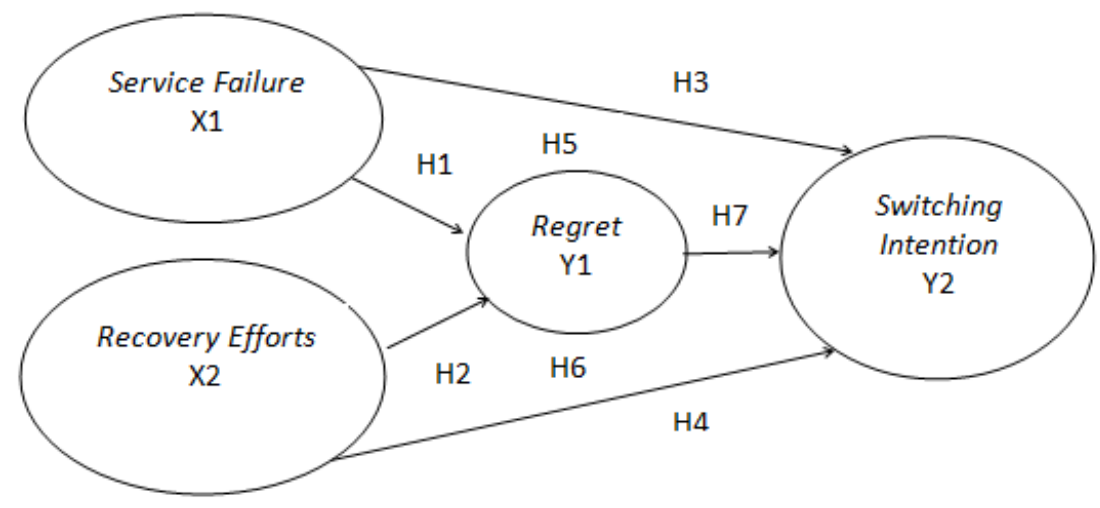


Gambar 2.1: Model Penelitian

Sumber: Le dan Ho (2019), diolah

\subsection{MATERIALS AND METHODS}

This study uses quantitative research methods. The data collection method used is a survey of AXA Mandiri insurance customers, for variable measurement using a 5-point Likert Scale, a questionnaire made in the form of a google form. The population is AXA Mandiri, insurance customers. The sample in this study is AXA Mandiri, insurance customers.

The sample size taken is 150 people. The sampling technique used to examine this research is a non-probability sampling technique with purposive sampling. Respondents who will be selected to be sampled in this study are respondents who meet the following conditions: a) Domiciled in the city of Surabaya, at least 18 years of age. b) Is an AXA Mandiri insurance customer and has experienced a service failure. In this study, the data analysis used is Structural Equation Modeling (SEM) through the LISREL program.

\subsection{RESULT}

\subsection{Reliability Test}

\section{Tabel 4.1}

Reliability Test

\begin{tabular}{|c|c|c|c|}
\hline Variable & CR & Cut off & Result \\
\hline Service Failure & 0,905 & $>0,7$ & Reliable \\
\hline Recovery Efforts & 0,847 & $>0,7$ & Reliable \\
\hline Regret & 0,917 & $>0,7$ & Reliable \\
\hline $\begin{array}{c}\text { Switching } \\
\text { Intention }\end{array}$ & 0,937 & $>0.7$ & Reliable \\
\hline
\end{tabular}

\subsection{Model Fit Te}

The results of the 11 Goodness of Fit test criteria listed, there are 2 criteria that are declared Un-Fit, 1 criterion are declared Marginal Fit and 8 criteria have met the Goodnes of Fit requirements.

\subsection{Structural Model Fit Test}

\section{Tabel 4.2}

Structural Equation

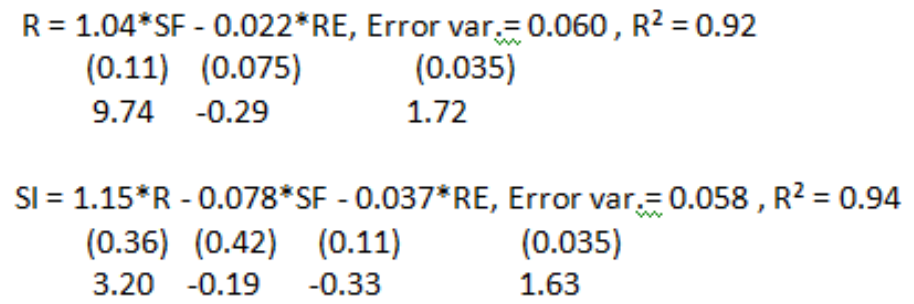




\section{Table 4.3}

Hypothesis testing

\begin{tabular}{|c|c|c|c|c|c|}
\hline Hypothesis & $\begin{array}{c}\text { Relationship of } \\
\text { Variable }\end{array}$ & $\begin{array}{c}\text { Loading } \\
\text { Factor }\end{array}$ & t-value & Cut off & Conclusion \\
\hline $\mathrm{H} 1$ & $\mathrm{SF} \rightarrow \mathrm{R}$ & 1,04 & 9,74 & 1,96 & Accepted \\
\hline $\mathrm{H} 2$ & $\mathrm{RE} \rightarrow \mathrm{R}$ & $-0,022$ & $-0,29$ & 1,96 & Rejected \\
\hline $\mathrm{H} 3$ & $\mathrm{SF} \rightarrow \mathrm{SI}$ & $-0,078$ & $-0,19$ & 1,96 & Rejected \\
\hline $\mathrm{H} 4$ & $\mathrm{RE} \rightarrow \mathrm{SI}$ & $-0,037$ & $-0,33$ & 1,96 & Rejected \\
\hline $\mathrm{H} 5$ & $\mathrm{SF} \rightarrow \mathrm{R} \rightarrow \mathrm{SI}$ & 1,19 & 2,98 & 1,96 & Accepted \\
\hline $\mathrm{H} 6$ & $\mathrm{RE} \rightarrow \mathrm{R} \rightarrow \mathrm{SI}$ & $-0,03$ & $-0,28$ & 1,96 & Rejected \\
\hline $\mathrm{H} 7$ & $\mathrm{R} \rightarrow \mathrm{SI}$ & 1,15 & 3,20 & 1,96 & Accepted \\
\hline
\end{tabular}

\subsection{DISCUSSION}

Based on the results of this study, it shows that Service Failure has a positive and significant effect on Regret, thus hypothesis 1 is accepted. Service failure and regret have a strong relationship. This proves that the service failure experienced by customers with AXA Mandiri insurance can cause regret (regret).

Recovery Efforts have a negative and insignificant effect on Regret, thus hypothesis 2 is rejected. Recovery efforts and regret have a weak relationship. This proves that the recovery efforts carried out by the insurance company AXA Mandiri, are not necessarily able to reduce the regrets experienced by customers.

Service Failure has a negative and insignificant effect on Switching Intention, so hypothesis 3 is rejected. Service failure and switching intention have a weak relationship. This proves that customers who experience service failure will not necessarily switch to insurance.

Recovery Efforts have a negative and insignificant relationship to Switching Intention, so hypothesis 4 is rejected. Recovery efforts and switching intention have a weak relationship. This proves that the recovery efforts made by the insurance company AXA Mandiri are not necessarily able to prevent customers from switching to other insurances.

Service Failure has a positive and significant effect on Switching Intention through Regret, thus hypothesis 5 can be accepted. Service failure, regret and switching intention have a strong relationship. This proves that the Service Failure carried out by the insurance company AXA Mandiri, can lead to switching intentions through regret.

Recovery efforts have a negative and insignificant effect on Switching Intention through Regret, thus hypothesis 6 can be rejected. Recovery efforts, regret and switching intention have a weak relationship. This proves that the recovery efforts carried out by AXA Mandiri insurance may not necessarily prevent customers from switching their intention to other insurance through regret.

Regret has a positive and significant effect on Switching Intention, thus hypothesis 7 can be accepted. Regret and switching intention have a strong relationship. This shows that the 
higher the regret (regret) experienced by AXA Mandiri insurance customers, the higher the intention to switch to other insurance.

Thus, for AXA Mandiri, the author would like to suggest several things related to improvements in its business operations:

1. AXA Mandiri Surabaya, prevents service failures by training employees to be proactive in responding to complaints from customers, then providing more than one customer service, and implementing improvement policies to resolve problems.

2. Prepare recovery efforts strategy, which relates to corrections, explanations, quick responses, fair treatment, sincere apologies and conveying customer complaints to superiors.

3. Prevent regrets. by understanding customer emotions which may help the company to choose the right action, including increasing recovery efforts and service quality, such as providing high empathy, providing fast responses to customers.

4. Prevent switching by improving services and implementing appropriate and effective recovery efforts policies and not repeating the same service failures over and over again.

\section{REFERENCE}

AXA Mandiri. (2015). AXA Mandiri Resmikan Kantor Layanan Nasabah Pertama di Surabaya. Didapatkan dari https://axa-mandiri.co.id/-/axa-mandiri-resmikan-kantorlayanan-nasabah-pertama-di-surabaya, 12 Maret 2021, Pukul 19.40 WIB.

Bisnis.com. (2019). Laba AXA Mandiri Turun 5,95\% Sepanjang 2018. Didapat dari https://finansial.bisnis.com/read/20190429/215/916714/laba-axa-mandiri-turun-595sepanjang-2018, 12 Maret 2021, Pukul 19.20 WIB.

Buchanan, J., Summerville, A., Lehmann, J., dan Reb, J. (2016). The regret elements scale: distinguishing the affective and cognitive components regret. Judgement and Decision Making, 11(3), 275 -286. $\sqrt{ }$

Chebab, S. (2010). The consumer regret. Moderators, Mediators and Consequences. Journal Of Business Studies Quartely, 1(4), 49-68.

Chuang, Y. F., dan Tai Y. F. (2016). Research on Customer Switching Behavior in the Service Industry. Management Research Review, 39(8), 925-939. V

DeWitt, T., Nguyen, D.T., dan Marshalla, R. (2008). Exploring customer loyality following service recovery: The mediating effects of trust and emotions. Journal of Service Research, 10(3), 269-281.

Harrison-Walker, L.J. (2019). The effect of consumer emotions on outcome behaviors following service failure. Journal of Service Marketing, 33(3), 285-302.

Huang, W., dan Zeelenberg, M. (2012). Investor regret: The role of expectation in comparing what is to what might have been. Judgment and Decision Making, 7(4), 441-451. Retrieved from http://journal.sjdm.org/11/11303/jdm11303.html $\sqrt{ }$

Hoang, C.C. (2020). Negative Emotions and Coping Behaviors of Passenger in the Airline Industry, Vietnam. Journal of Asian Finance, Economic, and Business, 7(10), 865874.

(10) Jabeen, S., Hamid, A. B. A., dan Rehman, S. U. (2015). Switching Intentions: A Case of Saudi Arabian Hypermarkets. International Journal of Economics and Financial Issues, 5(2), 215-222. V 
Jang, Y. J., Cho, S. B., dan Kim, W.G. (2013). Effect of Restaurant Patrons' Regret and Disappointment on Dissatisfaction and Behavioral Intention. Journal of Travel and Tourism Marketing, 30(5), 431-444.

Kim, G. M., Wang, C., dan Matilla, A.S. (2010). The relationship between consumer complaining behavior and service recovery : An integrative review. International Journal of Contemporary Hospital Management, 22(7), 975-991.

Le, A. N. H., dan Ho, H. X. (2019). The Behavioral Consequences Of Regret, Anger, and Frustration In Service Settings. Journal Of Global Marketing, 33(5), 1-20.

Liputan6.com. (2020). AXA Mandiri Bukukan Laba Bersih Rp 1 Triliun di 2019. Didapat dari https://www.liputan6.com/bisnis/read/4187475/axa-mandiri-bukukan-lababersih-rp-1-triliun-di-2019, 12 Maret 2021, Pukul 19.36 WIB.

Otoritas Jasa Keuangan. (2017). Asuransi. Didapatkan dari https://www.ojk.go.id/id/kanal/iknb/Pages/Asuransi.aspx, 12 Maret 2021, Pukul 14.00 WIB .

Pujiah, I. A., dan Fatmawati, F. (2018). Pengaruh Pelayanan yang Gagal Terhadap Respon Perilaku. Jurnal Manajemen dan Pemasaran Jasa, 11(1), 1-20.

Top Brand Award. (2015). Top Brand Index. Didapatkan dari https://www.topbrandaward.com/topbrandindex/?tbi_find=axa\%20mandiri, 12 Maret 2021, Pukul 19.00 WIB.

Top Brand Award. (2018). Top Brand Index. Didapatkan dari https://www.topbrandaward.com/topbrandindex/?tbi_find=axa\%20mandiri, 12 Maret 2021, Pukul 19.00 WIB.

Xu, X., Liu, W., dan Gursoy, D. (2018). The Impacts of Service Failure and Recovery Efforts On Airline Customers' Emotions and Satisfaction. Journal Of Travel Research, 58(6), 1034-1051. 